\title{
Packaging Development Center And Creative Industry As The Supporting Factors Of MSMEs To Compete In The Global Market
}

\author{
Yayan Suherlan \\ Fine arts Study Program \\ Facuty of Arts and Designs (FSRD) \\ Universitas Sebelas Maret (UNS) Surakarta, Indonesia
}

\author{
Nidyah Widyamurti \\ Three Year Diploma Program of Visual Communication \\ Designs \\ Facuty of Arts and Designs (FSRD) \\ Universitas Sebelas Maret (UNS) Surakarta, Indonesia \\ *Corresponding author: nidyah1234567890@gmail.com
}

\begin{abstract}
Packaging and marketing issues are still the weak points for micro, small and medium enterprises (MSMEs) engaged in food and beverage products. This is due to the low awareness and knowledge of MSMEs regarding to the importance of image, quality and packaging appearance, as well as the limited packaging service facilities that can improve the competitiveness of MSME products. This research has produced a model of MSME mentoring in the form of Creative Packaging and Industrial Development Center (BPKIK) which is integrated in Surakarta area as a solution to improve the competitiveness of food and beverage MSME products in the domestic and global markets. Most MSME producing food and beverage products in Surakarta do not have strong competitiveness yet in the market related to presentation and packaging problems; as much as $60 \%$ of the production technology, in terms of product and packaging, is done with conventional technology. Only $17 \%$ of the packaging has selling power. The Packaging Center and Creative Industry Model has been formulated with such types of services to facilitate MSMEs producing food and beverage products to develop their businesses. Recommendations are given at the implementation stage of the Packaging Center and Creative Industry model for regency / city level throughout Indonesia both with the name of BPKIK and other organizations.
\end{abstract}

Keywords : packaging, packaging hall, creative industry, MSMEs

\section{INTRODUCTION}

Prof. Carunia Mulya Firdausy (2017) explained that the slowing down of national economic growth is influenced by world economic growth and the target set by the Indonesian government is that by 2019 Indonesia's economic growth must reach 7\%, thus the development of creative economy certainly needs special attention.

In the Forum of Public Relations Coordination Body (Bakohumas), which was organized by the Public Relations of the Indonesian Ministry of Industry (Kemenperin) in Jakarta (Thursday, 07/26/2017), stated that the food and beverage industry is one of the leading manufacturers capable of contributing greatly to the national economy. Therefore, the food and beverage industry must be able to increase its competitiveness in the domestic and global markets. Abdul Rochim (Director of Beverage Industry, Tobacco Products, and Freshener of the Ministry of Industry) stated that the national food and beverage industry still has quite good growth potential, because it is supported by abundant natural resources and large domestic demand. The growth rate of the food and beverage industry in the first quarter of 2018 reached $12.70 \%$ and contributed to $35.39 \%$ of non-oil and gas industry GDP (http://www.kemenperin.go.id/ article / 19477 /).

The development of the food and beverage industry can be pursued through MSMEs, because MSMEs are small industries that start at home, where many people depend on it as the sources of their income. The development of MSMEs will have a broad impact on improving people's welfare. One alternative in increasing the productivity of MSMEs in food and beverage products is by modernizing the systemic business system and its policy tools which will have an impact on enhancing the competitiveness of MSMEs in food and beverage products in the domestic and global markets.

In addition, the basic thing that must get the attention of all stakeholders in Indonesia, especially MSME entrepreneurs of food and beverage products, is the importance of a change of perspective in addressing the competition that arises. External competition is no longer considered a threat, but as an opportunity to improve and become better, because the key to victory in a free market is competitiveness.

President Jokowi said at the opening of the Inacraft 2017 event at JCC Senayan Jakarta (Wednesday, 04/26/2017) that there are three key factors so that Indonesia's creative industry could continue to advance and compete internationally, namely: 1) understanding consumer tastes, 2) understanding the financial condition of consumers, and 3) punctuality at work. For this reason, efforts need to be made to empower MSMEs for food and beverage products to apply management principles, modern economic principles and product development. In addition, the problem of product, packaging and image presentation is a crucial problem faced by MSMEs for food and beverage products. Business actors must pay attention to 
product packaging so that buyers are interested (http://www.kemenperin.go.id/artikel/19477/).

In the current conditions, some MSMEs of food and beverage products are less aware of the importance of quality and product packaging in winning the competition. As the result, the products marketed tend to be ordinary, as they are, and there is no differentiating with the competitors' products. Packaging production services such as printing services are already widely available in Surakarta, but institutions such as the Creative Packaging and Industrial Development Center (BPKIK) which can to accompany the integrated competitiveness of MSME products are not yet available.

\section{LITERATURE REVIEW}

\section{A. Packaging}

Packaging is the activity of designing and producing containers or packs of a product (Kotler 1995: 200). Meanwhile Ying Li (2014) argued that product packaging is not only a powerful tool to market their products, but also represents the company's image. In the fierce market competition, it seems particularly important to pass the product information and corporate image on consumers quickly and accurately through product packaging. Thus, the main packaging function is as product protection and packaging, as product identity and information, as a marketing aid, and and product legality.

With the development of marketing and technology, packaging has experienced change of functions. The concept of "packaging protects what it sells" has been replaced by the concept of "packaging sells what it protects" (Hermawan, 1996). At present, products are purchased not only based on functional benefits, but also for emotional benefits (emotional reasons).

This type of packaging is divided into three types, namely: primary packaging, secondary packaging, and tertiary packaging. Primary packaging is a package that is in direct contact with the product. Secondary packaging is the packaging used to package several products in primary packaging, whereas tertiary packaging is a package that acts as a safety in the product distribution process. In general the packaging design goals are:

a. Showing the unique attributes of a product to differentiate with other products, this is an attempt to attract attention.

b. Strengthening the aesthetic appearance and product value.

c. Maintaining uniformity in the unity of the product brand.

d. Strengthen the difference between product variety and product line.

e. Developing different packaging forms according to categories.

f. Using new materials and develop innovative structures to reduce costs, be more environmentally friendly, or improve

functionality (Klimchuk, 2007: 49).

Packaging materials for food and beverage products require special specifications, NSW Government explained that for a food contact surface, to be considered food grade it must be able to be effectively cleaned, and must be made from a material that will not migrate into, contaminate or taint the food. The requirements for a plastic to be considered food grade are listed in the Australian Standard for Plastics materials for food contact use (AS2070-1999). Some points to be emphasized are that food packaging should be: 1) Made from suitable materials, 2) cleaned effectively, and 3) a single use items not to be reused.

Benny (2014: 15) emphasized that packaging can also play a role in communicating a particular image. All products sold in the market must be planned properly. If the manufacturer wants to launch a new product, one of the important tasks is to make the packaging stand out, different from the others and unique. If it does not give a different impression from other products, the new product will "sink". Consumers will catch the impression communicated by the packaging before trying the contents. Thus the packaging of the new product must be able to compete with the packaging of other products.

Packaging design is an activity of designing and producing packaging. This process is carried out with orientation to to market needs and trends at the time. From a consumer perspective, packaging design should clearly reveal the attributes and features of the product; and from a company perspective, packaging design should effectively promote sales. The basic procedure of package designing is designer's plan or arrangement on the whole design activity so as to achieve his/her goal of package design, which properly arranges the working steps in accordance with some scientific rules in order to achieve the overall objective (Ying Li , 2014: 886)

Scheme 1.Processes in designing a packaging Source: Ying Li (2014:884)

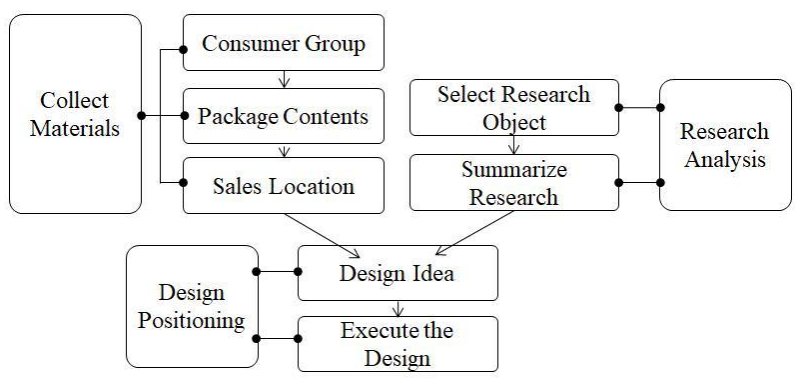


In packaging food and beverage products, the Government of Indonesia has established policies / regulations based on the characteristics of food and beverage products, including: (1) Republic of Indonesia Law No.18 of 2012 on Food, (2) Republic of Indonesia Government Regulation No.69 of 1999 on Food Labels and Ads, (3) Government Regulation No.28 of 2004 on Quality of Food Safety and Nutrition, (4) Regulation of the Head of Drug and Food Supervisory Agency (BPOM) of the Republic of Indonesia No. HK 05.05.55.6497 on Food Packaging Materials, (5) Regulation of the Minister of Health of the Republic of Indonesia No.329 / Menkes / XII / 76 on Food Production and Distribution, (6) Regulation of the Head Food and Drug Supervisory Agency of the Republic of Indonesia No. Hk.00.05.1.55.1621 on Supervision of Importation of Food Packaging Materials, (7) Regulation of the Head of Food and Drug Supervisory Agency of the Republic of Indonesia No.12 of 2015 on Supervision of Drug and Food Entry into the Territory of Indonesia (Nidyah, 2017).

\section{B. Packaging and Creative Industry Development Center}

In Indonesia, there have been several companies in the form of $\mathrm{CV}$ (Commanditaire Vennootschap) with services provided similar to the model of Packaging and Creative Development Center (BPKIK), such as: Rumah Kemasan Bandung, Bandung Packaging House, Rumah Besar Kemasan Mojokerto, and AA Packaging House Malang. There is also Denpasar Design Center as a counseling institution for MSMEs established by the Industry and Trade Office of Denpasar.

These companies and institutions provide services, including: a) Packaging Consultation, b) Business Development Consultation, c) Consultation on Market Access (Traditional and Modern) and the Association of SMIs / SMEs / Micro Enterprises, d) Packaging Design Services Unit, e) Packaging Production Services Units, f) IPR Clinic Unit, g) Research and Development Unit, h) Marketing Unit, and other activities. Solo Raya (Surakarta City, Boyolali Regency, Sukoharjo Regency, Wonogiri Regency, Sragen Regency, and Klaten Regency) with various local wisdoms in the field of food and beverage products do not have the MSME mentoring institutions of the same type of companies and institutions above. For this reason, it is necessary to establish Packaging and Creative Development Center for the Solo Raya region which will be a mentor to MSMEs of food and beverage products.

\section{MSMEs in Solo Raya Region}

Why are MSMEs food and beverage products? Because these MSMEs are a form of business that usually develop from home industries and still needs assistance in developing their businesses.

In Surakarta, there are around 5,000 MSMEs from various business sectors. And considering that BPKIK's market opportunity is not only for MSMEs for food and beverage products, the figures simply illustrate the range of market opportunities for the existence of BPKIK in Solo Raya in the future. The increase in the number of MSMEs in Surakarta is quite significant based on data in 2011 which reached 55,206,444 units with increase percentage of $2.02 \%$ for the increase of $1,091,623$ units in 2010 2011.

\begin{tabular}{|c|c|c|c|c|c|c|c|c|}
\hline \multirow{2}{*}{ No } & \multirow{2}{*}{ INOKATOR } & \multirow{2}{*}{ SATUAN } & \multicolumn{2}{|c|}{ TAHUW 2010} & \multicolumn{2}{|c|}{ TAHUW $2011^{7}$} & \multicolumn{2}{|c|}{$\begin{array}{l}\text { PERKEMBANGAN } \\
\text { 2010-2011 }\end{array}$} \\
\hline & & & JUMАН & $\begin{array}{c}\text { PAMGSA } \\
\text { (M) }\end{array}$ & UMLAH & $\begin{array}{l}\text { PANGSA } \\
(x)\end{array}$ & ЈЈМАн & (凩) \\
\hline (11) & (2) & (3) & (4) & 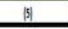 & (16) & $m$ & 部 & 酐 \\
\hline 1 & UNT USAHA $(A+B)$ & (Wnit) & 53.828569 & & 55.211 .396 & & 1.382827 & 2,57 \\
\hline & A. Usaho Mikro, Keid don Menengah (UWKM) & (Whit) & 54.114 .821 & 10,53 & 55.206 .44 & 29,99 & 1.091 .623 & 2,02 \\
\hline & - Uscho Miko (UMS) & (Unit) & 53.504 .416 & 99,40 & 545599969 & 98,82 & 1055553 & 1,97 \\
\hline & - Usaho Kedi(UK) & (Unit) & 568397 & 1,06 & $602: 195$ & 1,09 & 33.798 & 5,95 \\
\hline & - Uscho Menergah(UM) & (Wnit) & 42008 & 0,08 & 4.280 & 0,08 & 2.272 & 5,41 \\
\hline
\end{tabular}

\section{RESEARCH METHOD}

A. Research Design

This research applied action research, with the following stages:

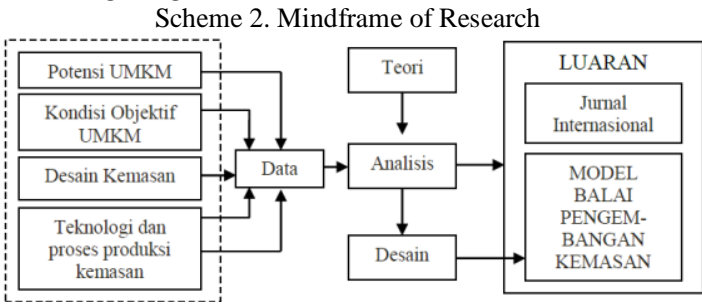

\section{B. Research Benefits and Objectives}

General objective: to develop knowledge and craftmanship on packaging and to improve packaging design to support the development of MSMEs for food and beverage products in Solo Raya.

a. Identifying internal and external factors of BPKIK development in Surakarta.

b. Formulating strategies for BPKIK development in Surakarta.

c. Formulating service model of BPKIK for MSMEs in Surakarta

C. Data Collection Technique

Structured and unstructured interviews as well as field observations in research locations, data source activities, and image recordings were carried out in the search for data from primary sources to the Office of Cooperatives and MSMEs of Surakarta, Boyolali, and Sukoharjo. The data from secondary resource persons were collected from thirty food and 
beverage MSMEs in Surakarta as sampling. The interviews were conducted to get a more complete picture of the problem faced and the development program in the future from each resource person's perspective and competence personally.

FGD (Focus Group Discussion) was conducted to present the discussion participants who are competent in the field of packaging technology, food technology, design, and marketing management.

In the preparation of management concepts and BPKIK development strategies for Surakarta comparative studies have been carried out at the Rumah Kemasan Bandung (RKB) and Packing House Bandung (PBH).

The documents and archives studied were in the forms of objective data on MSMEs for food and beverage products in Surakarta, Boyolali, and Sukoharjo, as means to look at the potential and market opportunities of these MSMEs. The documents were in the form of MSME profiles for food and beverage products and reputation data of MSMEs for food and beverage products at the Cooperatives and MSMEs Service in Surakarta, Boyolali, and Sukoharjo.

\section{Data Analysis Technique}

The collected data were presented in the form of tables, schemes, and records to be analyzed descriptively. To find out internal and external factors that influence the development of the BPKIK model, IFE (Internal Factor Evaluation) matrix and EFE matrix (external Factor Evaluation) were used, and to formulate the BPKIK development strategy, a strategy formulation was carried out through three stages: input stage, matching stage, and decision stage.

\section{RESULTS AND DISCUSSIONS}

A. Packaging and Creative Industry Development Center in Surakarta.

The existence of BPKIK in Surakarta is motivated by internal factors and external factors. The internal factors of BPKIK relate to internal resource needs which will be the carrying capacity of the internal performance of the organization, while the external factors of BPKIK relate to resource needs which will be the supporting capacity in organizational performance in relation to its development programs.

1. Vision

To become a center for packaging design development and MSME product marketing.

2. Mission
a. To assist the development of packaging design and production for MSMEs.
b. To Facilitate MSME business and business development.
c. To Facilitate market access.
d. To Facilitate legality / business licensing.

3. Objective of BPKIK
To become a MSME mentoring institution in managing and developing its business.

4. Target of BPKIK

In order to maximize its function, a network system of cooperation with various stake holder parties is very important for BPKIK. Collaboration should be carried out to complement an integrated set of activities. The possible parties that are able to coordinate are the Regional Government, MSMEs, Universities as Consultants, packaging material industry, printing industry, packaging equipment / machinery provider industry, Indonesian Advertising Association, Indonesian Packaging Federation, and institutions / agencies that issue approval and licensing.

Coordination should be conducted with the Regional Government in terms of establishing BPKIK, starting from licensing of BPKIK regulations or policies. In order to complete the facilities and infrastructure, it is necessary to coordinate with the materials and packaging industry, as well as the printing industry after the establishment of BPKIK. At the stage of establishment, it is important to coordinate with licensing and packaging agencies / institutions / agencies. The coordination network with policy holders and product legalization continues to facilitate MSMEs in terms of business licenses (PIRT), BPOM certification, and halal certification.

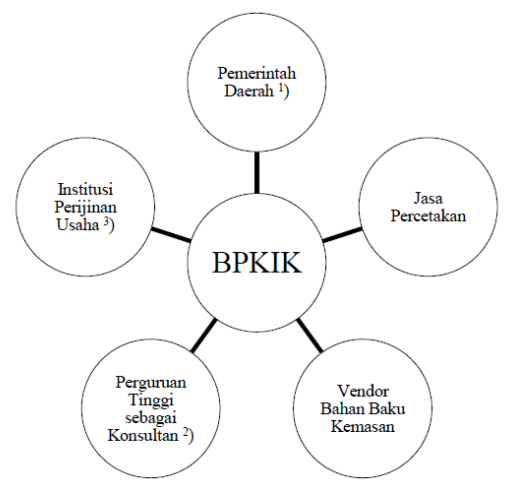

Scheme 3. Stakeholder of BPKIK

a. Regional Governments, especially the Department of Industry, the Trade Service, or the Cooperative Service, depending on which department in the Regency / City area is in charge of MSMEs.

b. Higher Education as a Consultant in accordance with the competence of each scientific field.

c. Business Licensing Institutions include the Health Office, Clinical Laboratory, Department of Intellectual Property Rights, MUI, etc.

5. Users of Packaging Service Center

In accordance with the initial concept of its establishment, BPKIK services are prioritized on 
MSMEs for food and beverage products. But BPKIK can also open service and packaging assistance for anyone who needs these services, including: MSMEs non food and beverage products, industries and business groups, prospective entrepreneurs, and students as study / internship materials.

6. Institutional

BPKIK is designed based on the needs of MSMEs and related institutions in Surakarta according to direct research data analysis, so that its management can run effectively and efficiently, and that its vision, mission and objectives can be achieved in an organized and structured manner. Similarly, the form of the institution is adjusted to the location conditions (service area)

7. Facilities and infrastructure

Facilities and infrastructure needed by BPKIK include (Nidyah, 2017):

a. Building location which is selected in accordance with the principles of Good Manufacturing Practices (GMP).

b. Virtual office (digital media) in the form of websites, e-mails, or similar media, as well as various social media to display profiles, portfolios, and various services / products produced.

c. Work equipments in the forms of: computers for graphic design specifications, printers, scanners, DLSR cameras, softboxes, and other equipments.

B. Development Strategy for BPKIK in Surakarta Strategy is a complete plan to achieve organizational goals. According to Griffin (2003), an effective strategy relates to three organizational issues, namely: competence, scope, and allocation of resources. SWOT analysis considers strengths, weaknesses, opportunities, and threats. A good strategy is to exploit the opportunity and strength of the organization, while neutralizing threats and avoiding weaknesses. By using SWOT analysis, an organization can: a) choose a strategy that supports its mission and exploit its opportunities and strengths, b) neutralize its threats, and c) avoid its weaknesses.

The strategy emphasizes to utilize existing resources to achieve goals (Devi, 2014). Strategy is the art of optimizing superior resources in maximizing the achievement of performance goals. The key to success lies in the existence of synergies in achieving goals.

Scheme 4.Development Strategy of BPKIK in Surakarta

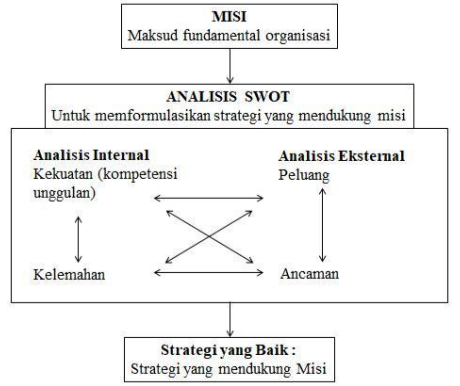

Through this scheme, it can be understood that SWOT Analysis is an important step in formulating a strategy. Based on the organization's mission, managers measure internal strengths and weaknesses (superior competencies), as well as external opportunities and threats, with the aim of developing good strategies that exploit opportunities and strengths, neutralize threats, and avoid weaknesses.

\section{Service Model of BPKIK for MSMEs in Surakarta}

Based on the SOP of the Packaging Development Center used in Denpasar Design Center, services at BPKIK for MSMEs include:

1. Packaging Consultation

a. Material consultation, design, and packaging production process.

b. Consultation of packaging production equipment requirements.

c. Consultation of packaging rules in accordance with government regulations.

d. Consultation of licensing and certification (such as: Circular Permit and BPOM(MD), Health Service (P-IRT), Intellectual Property Rights (IPR), and Patents, Barcodes, Halal Certificates, etc.).

2. Business Development Consultation

a. Development consultation and market expansion strategy.

b. Product development consultation.

c. Capital consultation.

d. Consultation on product production facilities.

e. As a motivator and collaborator.

3. Market access consultation (Traditional and Modern) and SME/ MSME/Micro Business association.

4. Packaging Design Service Unit

a. Packaging designer

b. Packaging graphic design

c. Promotional media Graphic design

5. Packaging Production Service Unit

6. IPR Clinic Unit

Assisting in IPR and Patent consultation as well as facilitating MSMEs in IPR and Patent management.

7. Research and Development Unit

Conducting research and development in design, production and training in theory and science by paying attention to local wisdom.

8. Marketing Unit

Conducting innovations in the field of marketing, designing marketing strategies, implementing marketing programs, and collaborating with parties that are able to provide supporting capacity in marketing units. 
Scheme 5. Service order for MSMEs in BPKIK in Surakarta

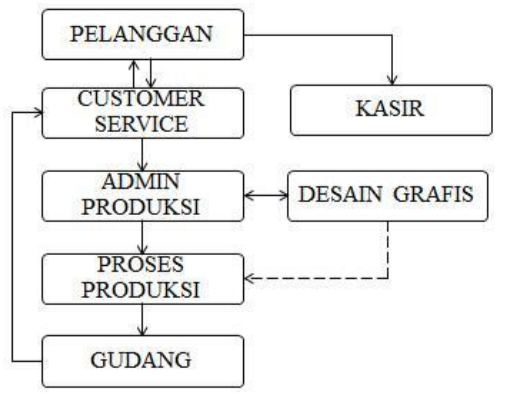

Scheme 6. Development of Creative Industry in BPKIK

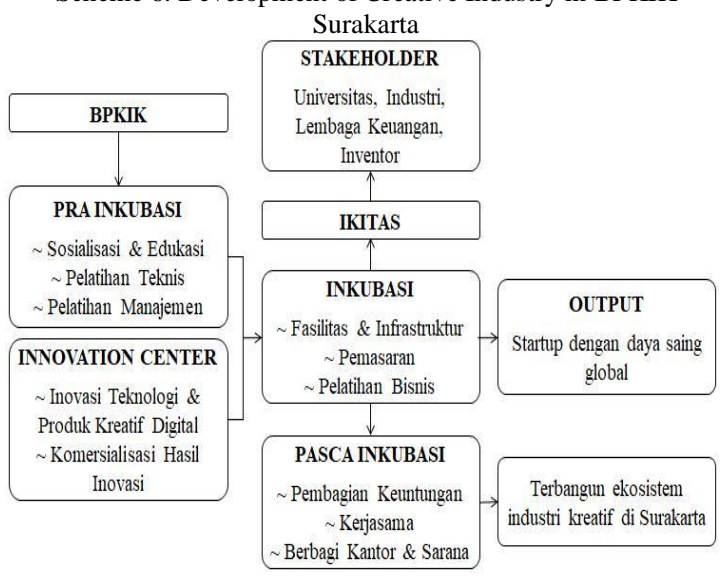

\section{CONCLUSION}

The results showed that the condition of MSMEs in Surakarta was not able to be at the level of global market competition, so it is necessary to provide an institution that is able to assist them. The Creative Packaging and Industrial Development Center (BPKIK) is the solution to the problem of declining number of MSMEs in the midst of market competition. Internal and external factors in the development of BPKIK in Surakarta have been fulfilled by the availability of resources.

BPKIK's development strategy in Surakarta can also be objectively pursued to be realized, and the BPKIK service model for MSMEs in Surakarta has also been well organized. Thus, it is likely that if BPKIK to be developed in Surakarta with the underlying background.

Services such as: Packaging Consultation, Business Development Consultation, Market Access Consultation (Traditional and Modern) and Association of IKM / UKM / Micro Business, Packaging Design Service Unit, Packaging Production Service Unit, IPR Clinic Unit, Research Unit and Development (R \& D), and Marketing Unit are offered in a combined model and strategy. For the sustainability of the packaging development center program, a serious handling is needed, as well as cooperation with various parties, such as stake and capital holders.

\section{REFERENCES}

\section{Journal}

Benny Rahmawan Noviadji. 2014. Desain Kemasan Tradisional Dalam Konteks Kekinian. ARTIKA Jurnal Fakultas Desain. Vol.1 Nomor 01 - Juli 2014. Program Studi Desain Komunikasi Visual, Fakultas Seni, Institut Informatika Indonesia (IKADO) Surabaya.

Ying Li, Kun Yao, Cong Song. 2014. Study On Packaging Design Positioning and Methods Based on Design Accuracy. Journal of Chemical and Pharmaceutical Research, 2014, 6(3):885-889. College of Arts, Hebei Normal University of Science \& Technology, Qinhuangdao, China. ISSN: 0975-7384. CODEN(USA) : JCPRC5. www.jocpr.com

Food Packaging and Shelf Life. ELSEVIER. An official journal of the Fraunhofer Institute for Process Engineering and Packaging, Freising, Germany. ISSN: 2214-2894

Book

Devi Puspita Sari, Mefrina Yusniar. 2014. PrinsipPrinsip Bisnis. Bogor: CV. Rizeva Utama.

Prof. Carunia Mulya Firdausy, MADE, Ph.D., APU (ed). 2017. Strategi Pengembangan Ekonomi Kreatif di Indonesia. Edisi I. Cetakan 1. Jakarta: Yayasan Pustaka Obor Indonesia. ISBN 978-602433-623-3

Griffin, Ricky W. 2003. Manajemen. Edisi terjemahan. Jakarta: Penerbit Erlangga.

Hermawan Kartajaya. 1996. Marketing Plus 2000 Siasat Memenangkan Persaingan Global. Jakarta: PT. Gramedia Pustaka Utama.

Kotler, Philip. 1987. Marketing 1. Jakarta: Penerbit Erlangga.

Nidyah Widyamurti, Asri Laksmi Riani. 2017. Panduan Pendirian dan Pembuatan Desain Kemasan. Badan Ekonomi Kreatif - Universitas Sebelas Maret Surakarta. Surakarta. ISBN: $987-$ 602-51050-7-4

Klimchuk, Marianne R. dan Sandra A. Krasovec. 2012. Packaging Design: Successful Product Branding From Concept to Shelf. $2^{\text {nd }}$ Edition. John Wiley \& Sons, Inc. Hoboken, New Jersey

\section{Other Sources}

NSW Government - Department of Primary Industries. 2015. Food Grade Packaging. Americas, Newington NSW 2127. www.foodauthority.nsw. gov.au _.../food_grade_pckg.pdf

\section{Digital Articles}

Eduardo Simorangkir. 2017. Jokowi ke Industri Kreatif: Bikin Kemasan yang Bagus. Detik Finance. $\quad$ https://finance.detik.com/beritaekonomi-bisnis/d-3484197/jokowi-ke-industrikreatif-bikin-kemasan-yang-bagus. Diakses tanggal 23 Agustusa 2018

Kemenperin Ungkap: Keunggulan Industri Makanan dan Minuman Kepada Peserta Bakohumas. http://www.kemenperin.go.id/artikel/19477/. Diakses tanggal 31 Juli 2018 


\section{Other Sources}

\section{Informants}

Dinas Perindustrian dan Perdagangan kota Surakarta

Rumah Kemasan Bandung.

$\begin{array}{ll}\text { Website } & \text { www.rumahkemasanbandung.com } \\ \text { Facebook } & \text { Rumah Kemasan Bandung } \\ \text { Instagram } & \text { @ rumahkemasanbandung } \\ \text { Packaging } & \text { House Bandung } \\ \text { Website } \quad: \text { www.packaginghouse.co.id } \\ \text { Facebook } & \text { Packaging House Indonesia } \\ \text { Instagram }: \text { @ packaginghouse } \\ \text { Rumah Besar Kemasan Mojokerto } \\ \text { Website } \quad: \text { www.kemasanukm.co.id } \\ \text { Facebook } \quad \text { Indonesia Pengembangan Kemasan UKM }\end{array}$

Instagram : @ kemasanukmpolos

AA Packaging House Malang Website : www.kemasan.net

Facebook : AA Packaging House Indonesia Instagram : @aapackaging

Denpasar Design Centre :

Website denpasardesigncentre.balidenpasartrading.com/ Facebook : Denpasar Design Centre

Instagram :@denpasardesigncentre

\section{Other References}

SOP Balai Pengembangan Kemasan.pdf 